\title{
ANALISIS KONSEP DIRI ANAK YANG TINGGAL DI PANTI ASUHAN ANALYSIS SELF CONCEPT OF CHILDREN LIVING IN ORPHANAGE
}

\author{
Romlah Dewi, Puji Setya Rini \\ Program Studi IImu Keperawatan STIKes Muhammadiyah Palembang \\ puipuijsetyarini@gmail.com
}

\begin{abstract}
ABSTRAK
Latar Belakang: Konsep diri mulai berkembang sejak masa bayi dan terus berkembang sejalan dengan perkembangan individu itu sendiri. Anak usia sekolah, merupakan usia anak dengan berbagai macam karakterisitik yang mempunyai konsep dari pada pandangannya atau penilaian individu lain terhadap dirinya sendiri, baik bersifat fisik, sosial, maupun psikologis yang di dapat dari hasil interaksinya dengan orang lain. Tujuan dalam penelitian ini untuk mengetahui konsep diri anak yang tinggal di panti asuhan.

Metode: Desain penelitian yang digunakan adalah observasional analitik dengan pendekatan evaluation research secara univariat yaitu melakukan penilaian terhadap pelaksanaan kegiatan program yang sedang dilakukan dalam rangka mencari umpan balik dan tehnik pengambilan sampel dengan menggunakan tehnik total sampling sebanyak 40 responden.

Hasil : Hasil penelitian gambaran konsep diri anak usia 6-12 tahun meliputi gambaran diri positif $20(50 \%)$ responden negatif $20(50 \%)$, ideal diri realistis $19(47 \%)$ dan tidak realistis $21(53 \%)$ responden, harga diri tinggi 22 (55\%) responden, rendah 18( 45\%) peran diri berperan $22(55 \%)$ responden, tidak berperan 18 (45\%) responden, dan identitas diri kuat $17(47 \%)$ responden, tidak kuat $23(58 \%)$ responden.

Kesimpulan : Hendaknya anak yang tinggal di panti asuhan dapat menjaga konsep diri sehingga memudahkan interaksi sosial sehingga individu yang bersangkutan dapat mengantisipasi reaksi orang lain.
\end{abstract}

\section{Kata kunci : Konsep Diri, Anak, Panti Asuhan}

\section{ABSTRACT}

Background: The concept of self began to develop from infancy and continues to develop in line with the development of the individual itself. school age children, is the age of children with a variety of characteristics that have concepts from their views or other individual assessments of themselves, both physical, social, and psychological in the results of their interactions with others. The purpose of this study was to determine the selfconcept of children living in orphanages.

Methods: The research design used was observational analytic with a univariate evaluation research approach which was to carry out an assessment of the implementation of the program activities being carried out in order to seek feedback and sampling techniques using a total sampling technique of 40 respondents.

Results The results of the study of self-concept of children aged 6-12 years include positive self-image 20 (50\%) negative respondents 20 (50\%), realistic self-ideal 19 (47\%) and unrealistic 21 (53\%) respondents, high self-esteem 22 (55\%) respondents, low 18 (45\%) self-role plays 22 (55\%) respondents, does not play 18 (45\%) respondents, and self-identity is strong 17 (47\%) respondents, not strong 23 (58\%) respondents .

Conclusion:Children who live in orphanages should be able to maintain their self-concept so as to facilitate social interaction so that the individual can anticipate the reaction of others.

Keywords : Self Concept, Children, Orphanage 


\section{PENDAHULUAN}

Pada era globalisasi dan modernisasi saat ini, terjadi banyak perubahan - perubahan baik dalam segi ekonomi, politik maupun sosial budaya. Perubahan yang cepat memberikan konsekuensi bagi individu untuk dapat menyesuaikan diri dengan tuntutan lingkungan yang semakin lama semakin meningkat. Tuntutan untuk menyesuaikan diri dengan lingkungan mengakibatkan perubahan nilai-nilai sosial budaya yang berpengaruh pada konsep diri dan perilaku seseorang (Mayasari, 2008).

Konsep diri adalah pandangan pribadi yang dimiliki seseorang tentang diri sendiri atau persepsi terhadap aspek diri yang meliputi aspek fisik, aspek sosial dan aspek psikologis yang interaksi terhadap orang lain (Sobur, 2009). Semenjak konsep diri terbentuk, seseorang akan berperilaku sesuai dengan konsep dirinya tersebut. Apabila perilaku seseorang tidak konsisten dengan konsep dirinya, maka akan muncul perasaan tidak nyaman dalam dirinya. Sehingga pandangan seseorang terhadap dirinya akan menentukan tindakan yang diperbuat (Arini, 2006).

Konsep diri mulai berkembang sejak masa bayi, dan terus akan berkembang sejalan dengan perkembangan individu itu sendiri. Pada awalnya terbentuk pengertian samarsamar, yang merupakan pengalaman berulang-ulang, yang berkaitan dengan kenyamanan atau ketidak nyamanan fisik, sehingga pada akhirnya akan membentuk konsep dasar sebagai bibit dari konsep diri. Jika anak diperlakukan dengan kehangatan dan cinta, konsep dasar yang muncul mungkin berupa perasaan positif terhadap diri sendiri, sebaliknya jika anak mengalami penolakan, yang tertanam adalah bibit penolakan diri yang akan datang. Pada tahun 2013 dari 3348 panti asuhan hanya 1270 yang terbina oleh puskesmas wilayah kerjanya (Riskesdas, 2013). Hal ini mengindikasikan belum terbinanya anak-anak yang tinggal di panti asuhan secara optimal.

Seseorang dengan konsep diri negatif akan cenderung bersikap pesimistik terhadap kehidupan dan kesempatan yang dihadapinya. la tiadak melihat tantangan sebagai kesempatan, namun lebih sebagai halangan. Orang dengan konsep diri negatif akan mudah menyerah sebelum berperang dan jika gagal, akan ada dua pihak yang di salahkan, entah itu menyalahkan diri sendiri (secara negatif) atau menyalahkan orang lain.

Sebaliknya seseorang dengan konsep diri yang positif akan terlihat lebih optimis, penuh percaya diri dan selalu bersikap positif terhadap segala sesuatu, juga terhadap kegagalan yang di alaminya. Kegagalan bukan di pandang sebagai kematian, namun menjadikannya sebagai penemuan dan pelajaran berharga untuk melangkah kedepan. Orang dengan konsep diri yang positif akan mampu menghargai dirinya dan melihat hal-hal yang positif yang dapat dilakukan demi keberhasilan di masa yang akan datang. Dari uraian di atas, dapat di simpulkan bahwa konsep diri adalah pandangan atau penilaian indivindu terhadap dirinya sendiri, baik yang bersifat fisik, social, maupun psikologis, yang didapat dari hasil interaksinya dengan orang lain. Seseorang dikatakan mempunyai konsep diri negatif jika ia meyakini dan memandang bahwa dirinya lemah, tidak berdaya, tidak dapat berbuat apa-apa, tidak kompeten, gagal, malang, tidak menarik, tidak disukai dan kehilangan daya tarik terhadap hidup. 
Setiap indivindu/ seseorang cenderung mengharapkan dirinya berkembang dan dapat menjadi lebih baik lagi. Perkembangan kemampuan/potensi seseorang tidak akan terwujud begitu saja apabila tidak diupayakan dan seberapa jauh seseorang mengupayakan sehingga mewujudkan potensinya menjadi aktual dan terwujud dalam sikap kepribadian. $\mathrm{Hal}$ ini dapat diperoleh apabila seseorang tersebut setidaknya memiliki rasa percaya dan konsep diri.

Anak yang memiliki konsep diri atau sesuatu kepribadian maka anak tersebut tidak akan pernah menjadi dirinya sendiri yang sesungguhnya, untuk itu perkembangan konsep diri anak disini dimaksudkan agar anak itu harus dapat mentukan pilihan, tujuan atau rencana untuk menentukan masa depannya.

Hal ini menegaskan bahwa sangat pentingnya mengenali diri sendiri atau konsep diri yang membedakan antar individu yang satu dengan individu yang lain. Agar anak dapat menilai kemampuan dirinya dalam memainkan peranan sosial, apakah baik, sedang, atau buruk, dan dalam keadaan demikianlah ia mengembangkan konsep dirinya, yang menunjukan kesan dan keyakinan mengenai karakteristik diri sendiri. Sehingga perkembangan konsep diri akan tumbuh pada segi kognitif dan afektif, indivindu akan mengevaluasi dirinya secara realistis dan positif, evaluasi ini berkembang berdasarkan pengalaman-pengalaman terhadap diri dimana diri sendiri sebagai objek persepsi maupun pengalamanpengalaman sebagai hasil belajar dan penilaian terhadap lingkungan, termasuk penilaian orang lain terhadap dirinya. Dengan tahap itu indivindu anak akan mencapai gambaran diri (self image) yang utuh, suatu pemahaman terhadap diri dalam keseluruhan dalam aspek yang mungkin bagi aktualisasi dirinya.

Menurut penelitian Nurfiah Abdullah pola tentang hubungan pola asuh orang tua dengan konsep diri anak usia sekolah, populasi dalam penelitian ini adalah siswa SD Aisiyiyah Dnoyo Usia 10-12 tahun, sebanyak 50 siswa, yang tersebar padda 3 kelas yakni kelas 4 berjumlah 17 siswa, kelas 5 sebanyak 20 siswa dan kelas 6 sebanyak 13 siswa. Hasil penelitian tersebut menunjukan nilai $r=0,689$ dan sig. ( 2 - tailed) $=0,000$ dengan demikian korelasi antara pola asuh orang tua dengan konsep diri anak usia sekolah kuat. Dari hasil penelitian tersebut dapat disimpulkan bahwa pola asuh orang tua yang positif dapat menghasilkan konsep diri yang positif pula. Bagaimana dengan anak usia sekolah yang tinggal di panti asuhan.

Menurut Departemen Sosial Republik Indonesia (1989), panti asuhan adalah suatu lembaga usaha kesejahteraan sosial yang mempunyai tanggungjawab untuk memberikan pelayanan kesejahteraan sosial kepada anak terlantar serta melaksanakan penyantunan dan pengentasan anak terlantar, memberikan pelayanan pengganti atau perwalian anak dalam memenuhi kebutuhan fisik, mental dan sosial pada anak asuh sehingga memperoleh kesempatan yang luas, tepat dan memadai bagi perkembangan kepribadiannya sesuai dengan yang diharapkan sebagai bagian dari generasi penerus cita-cita bangsa dan sebagai insan yang akan turut serta aktif dalam bidang pembangunan nasional.

Berdasarkan Studi Pendahuluan yang dilakukan peneliti berdasarkan informasi yang diperoleh peneliti dari ketua panti asuhan, anak yang tinggal di panti ditatangkan dari dina sosial dan 
ada juga yang di datangkan dari wakil wali anak tersebut. Dari 80 dengan rentang umur termuda 4 tahun dan yang tertua 22 tahun, terkategori ada 40 anak yang berusia antara 6-12 tahun, usia 6 tahun ada 3 anak, 10 tahun ada 11 anak dan 12 tahun ada 18 anak dan 10 anak terkategori usia sekolah, empat diantaranya terkategori mempunyai konsep diri rendah.

Berdasarkan uraian di atas, penulis tertarik untuk melakukan penelitian mengenai "Analisis Konsep Diri Anak Yang Tinggal Di Panti Asuhan".

\section{METODE PENELITIAN}

Desain penelitian yang digunakan adalah observasional analitik dengan pendekatan evaluation reseacrh secara univariat yaitu untuk melakukan penilaian terhadap pelaksanaan kegiatan program yang sedang dilakukan dalam rangka mencari umpan balik (Elfindri, 2012). Dalam hal ini memberikan gambaran konsep diri anak usia 6-12 tahun yang tinggal di panti asuhan.

Populasi dalam penelitian ini adalah semua anak yang tinggal di Panti ASUHAN.

\section{HASIL PENELITIAN}

\section{Analisis Univariat}

Analisis univariat dilakukan untuk mengetahui distribusi frekuensi dan presentase dari setiap variabel.

Tabel I Distribusi Frekuensi Responden Berdasarkan Gambaran diri

\begin{tabular}{ccc}
\hline $\begin{array}{c}\text { Gambaran } \\
\text { diri }\end{array}$ & Frekuensi & $\begin{array}{c}\text { Presentase } \\
(\%)\end{array}$ \\
\hline Positif & 20 & 50 \\
Negatif & 20 & 50 \\
\hline Jumlah & 40 & 100 \\
\hline \multicolumn{3}{c}{ Berdasarkan tabel 1 diatas dapat } \\
diketahuai bahwa dari 40 responden
\end{tabular}

yang memiliki gambaran diri positif sebanyak 20 responden (50\%) sedangkan responden yang memiliki gambaran diri positif sebanyak 20 responden $(50 \%)$.

Tabel II Distribusi Frekuensi Responden Berdasarkan Ideal diri Ideal diri Frekuensi Presentase

\begin{tabular}{ccc} 
& & $(\%)$ \\
\hline Realistis & 19 & 47 \\
Tidak & 21 & 53 \\
Realistis & & \\
\hline Jumlah & 40 & 100
\end{tabular}

Berdasarkan diatas dapat diketahuai bahwa dari 40 responden yang memiliki Ideal diri Realistis sebanyak 19 responden (47\%) sedangkan responden yang memiliki Ideal diri tidak realistis sebanyak 21 responden (53\%).

Tabel III Distribusi Frekuensi Responden Berdasarkan Harga Diri

\begin{tabular}{ccc}
\hline $\begin{array}{c}\text { Harga } \\
\text { diri }\end{array}$ & Frekuensi & $\begin{array}{c}\text { Presentase } \\
(\%)\end{array}$ \\
\hline Tinggi & 22 & 55 \\
Rendah & 18 & 45 \\
\hline Jumlah & 40 & 100 \\
\hline
\end{tabular}

Berdasarkan diatas dapat diketahuai bahwa dari 40 responden yang memiliki Harga diri Kuat sebanyak 22 responden $(55 \%)$ sedangkan responden yang memiliki harga diri Rendah sebanyak 18 responden $(45 \%)$.

Tabel IV Distribusi Frekuensi Responden Berdasarkan Peran diri

\begin{tabular}{|c|c|c|}
\hline Peran diri & Frekuensi & $\begin{array}{c}\text { Presentase } \\
(\%)\end{array}$ \\
\hline Berperan & 22 & 55 \\
\hline $\begin{array}{c}\text { Tidak } \\
\text { berperan }\end{array}$ & 18 & 45 \\
\hline Jumlah & 40 & 100 \\
\hline
\end{tabular}


sebanyak 22 responden (55\%) sedangkan responden yang Tidak berperan sebanyak 18 responden (45\%).

Tabel V Distribusi Frekuensi Responden Berdasarkan Identitas diri

\begin{tabular}{ccc}
\hline $\begin{array}{c}\text { Identitas } \\
\text { diri }\end{array}$ & Frekuensi & $\begin{array}{c}\text { Presentase } \\
(\%)\end{array}$ \\
\hline Kuat & 17 & 42 \\
Lemah & 23 & 58 \\
\hline Jumlah & 40 & 100 \\
\hline
\end{tabular}

Berdasarkan diatas dapat diketahuai bahwa dari 40 responden yang memiliki identitas diri Kuat sebanyak 17 responden (42\%) sedangkan responden yang memiliki identitas diri Rendah sebanyak 23 responden (58\%).

\section{PEMBAHASAN}

\section{A. Pembahasan Hasil Penelitian}

Berdasarkan Hasil penelitian diatas dapat diketahuai bahwa dari 40 responden yang memiliki.

\section{Gambaran diri}

Gambaran diri positif sebanyak 20 responden $(50 \%)$ sedangkan responden yang memiliki gambaran diri positif sebanyak 20 responden (50\%).

Gambaran diri adalah sikap seseorang terhadap tubuhnya secara sadar dan tidak sadar. Sikap ini mencakup persepsi dan perasaan tentang ukuran dan bentuk tubuh, fungsi, penampilan dan potensi tubuh saat ini dan masa lalu (Keliat, 1992).

Menurut Hadiwibowo (2003), gambaran diri berhubungan erat dengan kepribadian. Cara individu memandang dirinya mempunyai dampak yang penting pada aspek psikologisnya. Pandangan yang realistis terhadap diri, menerima dan menyukai bagian tubuh akan memberi rasa aman dan mampu meningkatkan keinginan untuk berhasil didalam kehidupan. Namun gambaran diri yang tidak benar akan membuat individu kehilangan jati dirinya serta menghambat kemampuan yang dimilikinya.

Hasil penelitian yang didilakukan oleh marga 2010, tentang hubungan gambaran diri dengan tingkat kecemasan ibu yang memiliki anak berkebutuhan khusus dikelurahan lhok keutapang tapak tuan, didapatkan hasil penelitian menunjukkan adanya korelasi positif yang signifikan antara gamabaran diri dengan tingkat kecemasan ibu $(p=0,02)$.

Hasil penelitian yang dilakukan oleh malita 2014, berpendapat bahwa semakin positif gambaran diri maka kecemasan akan menuru, gambaran diri yang baik dapat mendorong dalam sukses kehidupannya, meneriam dan menyukai bagian tubuh akan memberi rasa aman sehingga terhindar dari rasa cemas dan meningkatkan harga diri.

Berdasarkan hasil penelitian di panti asuhan, peneliti berasumsi bahwa gambaran konsep diri yang berjumlah 5 (lima) konsep kepribadian anak yang menyukai bagian tubuh akan memberi rasa aman dan mampu meningkatkan keinginan untuk berhasil didalam kehidupan, sikap seseorang terhadap tubuhnya secara sadar dan tidak sadar, sikap ini mencakup persepsi dan perasaan tentang ukuran, bentuk tubuh, kesehatan, fungsi penampilan dan potensi tubuh saat ini dan masa lalu yang secara berkesinambungan di modifikasi dengan pengalaman baru setiap individu.

\section{Ideal diri}

Ideal diri Realistis sebanyak 19 responden $(47 \%)$ sedangkan responden yang memiliki Ideal diri tidak realistis sebanyak 21 responden (53\%). 
Ideal diri terdiri atas aspirasi, tujuan, nilai dan standar perilaku yang dianggap ideal dan diupayakan untuk dicapai. Diri ideal berawal dalam tahun prasekolah dan berkembang sepanjang hidup. Diri ideal dipengaruhi oleh norma masyarakat dan harapan serta tuntutan dari orang tua dan orang terdekat (Potter dan Perry, 2005).

Hasil penelitian Hidayat 2012, pada mahasiswa profesi angkatan $X$ FKIK Unsoed, sebagai mahasiswa mereka mampu menyelesaikan tugas-tugas perkuliahan dengan baik. Pada penelitian ini hasil uji statistik Chi-Square identitas diri tidak mempengaruhi kesiapan bekerja pada mahasiswa angkatan $X$ FKIK Unsoed menjelang akhir masa profesi ners.

Berdasarkan hasil penelitian di panti asuhan, peneliti berasumsi bahwa Dalam menetapkan ideal diri hendaknya tidak terlalu tinggi, masih tinggi dan kemampuan individu, dan masih dapat dicapai, Diri ideal berawal dalam tahun prasekolah dan berkembang sepanjang hidup.

\section{Harga diri}

Harga diri Kuat sebanyak 22 responden (55\%) sedangkan responden yang memiliki harga diri Rendah sebanyak 18 responden (45\%).

Stuart dan Sundeen (dalam Keliat, 1992) menjelaskan bahwa harga diri adalah penilaian pribadi terhadap hasil yang dicapai dengan menganalisa seberapa jauh perilaku memenuhi ideal diri. Frekuensi pencapaian tujuan akan menghasilkan harga diri yang rendah/tinggi. Bila individu selalu sukses maka cenderung harga diri tinggi, sebaliknya bila ia sering gagal maka ia akan cenderung harga diri rendah. Harga diri diperoleh dari diri sendiri dan orang lain. Aspek utamanya adalah dicintai dan menerima penghargaan dari orang lain. Menyayangi dan menghargai orang lain akan mampu mengangkat harga dirinya. Begitu pula sebaliknya, dengan tidak adanya kasih sayang dan penghargaan maka akan terbentuk harga diri yang rendah (Santrock (2002).

Individu yang memiliki harga diri positif akan menerima dan menghargai dirinya sendiri apa adanya. Dalam harga diri tercakup evaluasi dan penghargaan terhadap diri sendiri dan menghasilkan sikap positif atau negatif terhadap dirinya sendiri. Sikap positif terhadap diri sendiri adalah sikap terhadap kondisi diri, menghargai kelebihan dan potensi diri, serta menerima kekurangan yang ada, sedangkan yang dimaksud dengan sikap negatif adalah sikap tidak suka atau tidak puas dengan kondisi diri dan tidak menghargai kelebihan diri dengan melihat diri sebagai sesuatu yang selalu kurang (Santrock, 1998).

Penelitian ini tidak sejalan diatas karena penelitian ini bertujuan untuk mengetahui hubungan antara harga diri dengan tingkat kecemasan, perbedaan tingkat kecemasan, siswa akselerasi perempuan dan siswa akselerasi lakilaki, serta perbedaan penyesuaian sosial siswa SMPN 2 dan siswa akselerasi SMP PL domenico=0,8986 alpha savio. Penelitian ini menggunakan skala sosial $(\mathrm{P}=0,9226)$ yang diberikan kepada 61 subjek alpha dan skala konsep diri penelitian sesuai yang dihipotesisnya ditemukan hubungan yang positif dan signifikan antara harga diri dengan tingkat kecemasan, baik di SMPN 2 maupun di SMP PI dan ditemukan juga bahwa terdapat perbedaan tingkat kecemasan siswa akselerasi SMPN 2 dengan siswa SMPL namun demikian tidak ditemukan perbedaan tingkat kecemasan siswa akselerasi perempuan 
dan siiswa akselerasi laki-laki dari kedua sekolah tersebut.

Berdasarkan hasil penelitian di panti asuhan, peneliti berasumsi bahwa Harga diri dapat diperoleh melalui orang lain dan diri sendiri. Aspek utama harga diri adalah dicintai, disayangi, dikasihi orang lain dan dapat penghargaan dari orang lain. Dalam harga diri tercakup evaluasi dan penghargaan terhadap diri sendiri dan menghasilkan sikap positif atau negatif terhadap dirinya sendiri.

\section{Peran diri}

Peran diri Berperan sebanyak 22 responden $(55 \%)$ sedangkan responden yang Tidak berperan sebanyak 18 responden (45\%).

Sebagian besar individu mempunyai lebih dari satu peran. Peran sebagai orang tua, sebagai pekerja dan sebagai pelajar atau mahasiswa. Setiap peran mencakup pemenuhan harapan tertentu dari orang lain. Pemenuhan harapan ini mengarah pada penghargaan. Ketidakberhasilan untuk memenuhi harapan ini menyebabkan penurunan harga diri atau terganggunya konsep diri seseorang (Potter dan Perry, 2005).

Penelitian ini sejalan dengan teori yang dikemukakan oleh Rahmat (2008) yang menyatakan bahwa peran diri adalah pola perilaku, sikap, nilai, dan aspirasi yang diharapkan individu berdasarkan posisinya dimasyarakat. Setiap individu disibukkan oleh berbagai macam peran yang terkait dengan posisinya pada setiap saat, selama dia masih hidup, misalnya peran sebagai anak, istri, ayah, suami, mahasiswa, perawat, dokter, bidan, dosen dan ketua $\mathrm{Rt}$ atau Rw. Konflik peran terjadi apabila peran yang diinginkan individu, sedang diduduki individu lain.

Berdasarkan hasil penelitian di panti asuhan, peneliti berasumsi bahwa
Peran yang tidak sesuai, terjadi apabila individu dalam proses peralihan mengubah nilai dan sikap. Misalnya, seseorang yang masuk anggota organisasi profesi keperawatan, terdapat konflik antara sikap dan nilai individu dengan profesi. Setiap individu disibukkan oleh berbagai macam peran yang terkait dengan posisinya pada setiap saat, misalnya sebagai ayah, ibu, anak mahasiswa, perawat, dokter, bidan, dosen, dan lain-lain

\section{Identitas diri}

Identitas diri kuat sebanyak 17 responden (42\%) sedangkan responden yang memiliki identitas diri rendah sebanyak 23 responden (58\%).

Pembentukan identitas diri seseorang tidak lepas dari tugas perkembangan yang berhasil dilalui, dimana dalam hal ini pula tingkat kematangan pada diri seseorang mempengaruhi pembentukan sikap dan pola perilaku pada identitas diri orang tersebut. kematangan seseorang dalam melalui tahap perkembangan tidak lepas dari proses belajar, yang merupakan hal penting dalam perkembangan. Di mana kematangan merupakan dasar untuk belajar menentukan pola prilaku seseorang (Hurlock, 1999).

Bahwa identitas diri memiliki peranan penting dalam menentukan perilaku individu sebagai cermin bagi individu dalam memandang dirinya. Individu akan bereaksi terhadap lingkungannya sesuai dengan konsep dirinya.

Identitas diri tentunya ada yang positif dan ada juga negatif. Berkaitan dengan pola asuh orang tua, juga memiliki pola asuh yang positif dan negatif. Paling tidak ada ciri-ciri konsep diri positif misalanya: Mempunyai penerimaan diri yang baik, Mengenal 
dirinya sendiri dengan baik, Dapat memahami dan menerima fakta-fakta yang nyata tentang dirinya, Mampu menghargai dirinya sendiri, Mampu menerima dan memberikan pujian secara wajar, Mau memperbaiki diri kearah yang lebih baik. Dan Mampu menempatkan diri di dalam lingkungan.

Hasil penelitian ini tidak jauh berbeda dari penelitian yang dilakukkan oleh esterlita (2011), tentang hubungan antara identitas diri dengan kecemasan ibu yang memiliki anak tunawicara di SLB N 3 Yogyakarta, didapatkan hassil penelitian menunjukkan bahwa hasil uji linearitas kedua variable menunjukkan nilai $F=61,010$ dengan taraf signifikan $0,000(p<0,05)$. Artinya hubungan antara identitas diri dengan kecemasan ibu yang memiliki anak tuna wicara dinyatakan linier.

Berdasarkan hasil penelitian di panti asuhan, peneliti berasumsi bahwa identitas diri seseorang tidak lepas dari tugas perkembangan yang berhasil dilalui, dimana dalam hal ini pula tingkat kematangan pada diri seseorang mempengaruhi pembentukan sikap dan pola perilaku pada identitas diri orang tersebut.

\section{KESIMPULAN DAN SARAN \\ Simpulan}

1. Distribusi frekuensi gambaran diri positif sebanyak 20 responden (50\%) sedangkan responden yang memiliki gambaran diri negatif sebanyak 20 responden $(50 \%)$.

2. Distribusi frekuensi Ideal diri realistis sebanyak 19 responden (47\%) sedangkan responden yang memiliki Ideal diri tidak realistis sebanyak 21 responden (53\%).

3. Distribusi frekuensi Harga diri tinggi sebanyak 22 responden (55\%) sedangkan responden yang memiliki harga diri rendah sebanyak 18 responden $(45 \%)$.

4. Distribusi frekuensi Peran diri peran sebanyak 22 responden (55\%) sedangkan responden yang memiliki gambaran diri tidak berperan sebanyak 18 responden (45\%)

5. Distribusi frekuensi identitas diri kuat sebanyak 17 responden (42\%) sedangkan responden yang memiliki identitas diri lemah sebanyak 23 responden (58\%).

\section{Saran}

1. Bagi Institusi Pendidikan.

Hendaknya hasil penelitian ini dapat digunakan sebagai salah satu sarana evaluasi konsep diri. Sehingga Individu akan bereaksi terhadap lingkungannya sesuai dengan konsep dirinya.

\section{Bagi Panti Asuhan}

Hendaknya seluruh anak-anak di panti asuhan, dapat benar-benar menjaga konsep diri anak, Sehingga memudahkan interaksi sosial sehingga individu yang bersangkutan dapat mengantisipasi reaksi orang lain. serta dapat meningkatkan mutu dari Panti Asuhan itu sendiri. Pihak panti diharapkan dapat meningkatkan peran sertanya dipanti asuhan khususnya anak yang tinggal dipanti asuhan tersebut dalam memberikan informasi kesehatan berupa penyuluhan dan memberikan motivasi kepada anak sehingga dapat memiliki konsep diri yang positif.

\section{Bagi Peneliti Selanjutnya.}

Disarankan untuk meneliti secara lebih mendalam tentang konsep diri anak usia 6-12 tahun, serta menguji lagi kevalidtan dari kuesioner, sehingga dapat diketahui 
secara mendetil perilaku konsep diri anak usia 6-12 tahun. Dan diharapkan dapat meneliti yang sama tapi menggunakan model kualitatif tentang konsep diri anak, sehingga dapat dijelaskan gambaran konsep diri anak usia 6-12 tahun.

\section{DAFTAR PUSTAKA}

Agoes Dariyo. (2004). Psikologi Perkembangan Remaja. Bogor: Ghalia Indonesia.

Andi Mappiare. (1992). Pengantar Konseling dan Psikoterapi. Malang: Rajawali Pers.

Angelis, Barbara De. (2003). Confidence Percaya Diri Sumber Sukses dan Kemandirian.Jakarta: PT. Gramedia Pustaka Utama.

Candy, Philip. (1991) Independent learning; Some ideas from the literature.Diakses dari

Conny Semiawan. (2002). Belajar dan Pembelajaran Prasekolah dan Sekolah Dasar. Jakarta: PT Indeks.

Chabib Thoha. (1996). Kapita Selekta Pendidikan Islam. Yogyakarta : Pustaka pelajar (IKAPI).

Dahlan, S (2008)."langkah-langkah Membuat Proposal Penelitian Kedokteran dan Kesehatan.Jakarta : CV. Sagung Seto.

Daryanto dan Muljo Rahardjo. (2012). Model Pembelajaran Inovatif. Malang: Gava Media.

Depdikbud. (1996). Kamus Besar Bahasa Indonesia. Jakarta: Balai Pustaka.

Djaali. (2007). Psikologi Pendidikan. Jakarta: PT Bumi Aksara.

Dudung Hamdung. (2009). The 7 Personalities of Success. Yogyakarta: Gara IImu.
Departemen kesehatan RI. (2013). Riset kesehatan Dasar. Jakarta : Depkes $\mathrm{RI}$.

Dermawan, Deden.(2012). Buku Ajar Keperawatan Komunitas. Yogyakarta: Gosyen Publishing

Hamdan. (2009). Hubungan Antara Kepercayaan Diri Dengan Motivasi Berprestasi Pada Siswa SMUN 1 Setu Bekasi. Skripsi. Depok: Universitas Gunadarma.

Haris Mudjiman. (2006). Manajemen Pelatihan Berbasis Belajar Mandiri. Yogyakarta: Pustaka Pelajar.

Haryanto. (2010). Pengertian Konsep Diri. Diakses dari http://belajarpsikologi.com/pengertiankonsep-diri/pada Tanggal 10 juni 2015 jam 22:13.

Hendrianti Agustianti. (2006). Psikologi Perkembangan. Bandung: PT Refika Aditama.

Hiemstra. (1994). Self-Directed Learning. In T. Husen \& T. N. Postlewaite (Eds), The International Encyclopedia of Education (second edition) Oxford: Porgomon Press. Diakses dari

Holsten, Hermann. (1984). Murid Belajar Mandiri. Penerjemah: Soeparmo. Bandung: CV Remadja Karya.

Hutagalung, Inge. ( 2007). Pengembangan Kepribadian Tinjauan Praktis Menuju Pribadi Positif. Jakarta: PT IndeksEffendy, Ferry dan Makhfudli. /2009/ Keperawatan Kesehatan Komunitas-Teori dan Praktek dalam Keperawatan.. Jakarta: Salemba Medika

Effendy, Nasrul. (1998). Dasar-Dasar Keperawatan Kesehatan Masyarakat Edisi 2. Jakarta: EGC

Elfindri dkk,(2010).Metodologi penelitian Kesehatan. Jakarta: Baduose Media Jakarta. 
Irianto,A.(2010).Statisitk Konsep dasar,Aplikasi

dan

Pengembangannya. Jakarta: Kencana Predana Media group.

Malita. (2014). Skripsi "Hubungan konsep diri dengan tingkat kecemasan pada orang tua anak tuna rungu di SLB B karya lbu Palembang Tahun 2014".Palembang: Program Studi IImu Keperawatan

Sekolah Tinggi Ilmu Kesehatan (STIKes) Muhammadiyah Palembang.

Mulyati. (2005). Psikologi Belajar. Yogyakarta: Andi Offset.

Pasaribu dan Simandjuntak. (1980). Proses Belajar Mengajar. Bandung: Tarsito.

Riwidikdo, H. (2010). Statistik Untuk Penelitian Kesehatan Dengan Aplikasi Program $R$ dan SPSS. Yogyakarta : Pustaka Rihama.

Retno Dwi Astuti. (2005). Pengaruh Pola Asuh Orang Tua Terhadap Kemandirian Siswa Dalam Belajar pada Siswa Kelas XI SMA Negeri Sumpiuh

Rika Eka Izzaty, dkk. (2008). Perkembangan Peserta Didik. Yogyakarta: UNY Press.

Rochmat Wahab dan Solehuddin. (1998). Pekembangan dan Belajar Peserta Didik. Yogyakarta: Depdikbud.

Rosnida Nurhayati. (2007). Pemanfaatan Website www.gomath.com sebagai Media dalam Peningkatan Kemandirian Belajar Matematika Siswa kelas XSMA N 1 Sleman Tahun Pelajaran 2006/2007. Skripsi. Yogyakarta: UNY.

Rusman. (2012). Model-Model Pembelajaran. Bandung: Rajawali Pers
Saryono \& Widianto, A. T. (2010). Catatan Kuliah: Kebutuhan Dasar Manusia

(KDM). Yogyakarta: Nuha Medika.

Schaefer, Charles. (1994) Bagaimana Mempengaruhi Anak. Jakarta: Dahara Press.

Schiller, Pam dan Bryant, Tamera. (1998). The Values Book for Children (16 Nilai Modal Dasar Bagi Anak). Penerjemah: Susi Sensusi. Jakarta: PT Elex Media Komputindo.

Siregar, Syofian. (2013). Metode Penelitian Kuantitatif Dilengkapi Perhitungan Manual SPSS. Jakarta: Kencana.

Slameto. (2010) Belajar dan FaktorFaktor yang Mempengaruhinya. Jakarta: Rineka Cipta.

Sugiyono. (2009). Metode Penelitian Kuantitaif Kualitatif dan $R \& D$. Bandung: Alfabeta.

Syaiful Bahri Djamrah dan Aswan Zain. (1997). Strategi Belajar Mengajar. Jakarta: Rineka Cipta.

Syaiful Sagala. (2010). Konsep dan Makna Pembelajaran untuk Membantu Memecahkan Problematika Belajar dan Mengajar. Bandung: Alfabeta.

Syamsu Yusuf. (2006). Program Bimbingan dan Konseling di Sekolah (SLTP dan SLTA). Bandung: Pustaka Bani Quraisy.

Walker, Edward. (1973). Conditioning dan Proses Belajar Instrumental. Penerjemah: Team Fakultas Psychologi Universitas Indonesia. Jakarta: Yayasan Penerbit Universitas Indonesia. 